\title{
ABSTRAK \\ Perbedaan Gejala pada Anak Autis yang Diet Bebas Gluten dan Kasein dengan yang Tidak Diet di Surabaya
}

Pendahuluan: Autisme berdasarkan DSM V adalah gangguan perkembangan pervasif yang ditandai dengan gangguan komunikasi, interaksi sosial dan perilaku repetisi yang terbatas. Salah satu terapi diet yang populer bagi penderita autistik berupa diet bebas gluten dan kasein. Diet bebas gluten dan kasein yang didasari oleh teori opioid sampai saat ini masih menjadi pro dan kontra sehingga ada tidaknya pengaruh dari diet ini perlu diteliti lebih lanjut. Metode: Penelitian analitik observasional rancangan cross sectional ini dilakukan pada anak autis berusia 3-12 tahun yang diterapi di beberapa pusat terapi autis di Surabaya dan telah didiagnosis oleh dokter ahli. Subyek penelitian dipilih dengan metode purposive sampling. Data pelaksanaan diet bebas gluten dan kasein diperoleh dari kuesioner FFQ dan data gejala pada anak autis diperoleh dari kuesioner ATEC. Analisis bivariat dilakukan dengan uji T2 sampel bebas bila distribusi normal dan Mann-Whiteney bila distribusi tidak normal. Hasil: Sebagian besar anak autis berjenis kelamin laki - laki (79\%), rata - rata umur anak autis $6-8$ tahun dan sebagian besar riwayat pendidikan orang tua adalah perguruan tinggi. Didapatkan hasil sebanyak 37 anak melaksanakan diet bebas gluten dan kasein. Skor ATEC baik pada domain kemampuan komunikasi, interaksi sosial, respon kognitif dan gangguan perilaku pada anak autis yang diet lebih rendah daripada yang tidak. Hasil uji bivariat menunjukkan ada perbedaan yang signifikan pada variabel gangguan perilaku $(\mathrm{p}=0,021)$ dan skor ATEC total $(\mathrm{p}=0,018)$. Sementara pada variabel lain tidak didapatkan perbedaan. Kesimpulan: Terdapat perbedaan perbedaan gejala pada anak autis yang diet bebas gluten dan kasein dengan yang tidak diet bebas gluten dan kasein.

Kata Kunci: autis, diet, gluten, kasein, gejala 


\section{ABSTRACT \\ Differences of Symptom in Autistic Children with Gluten and Casein Free Diet with Non Diet in Surabaya}

Introduction: Autism is a pervasive development disorder characterized by impaired communication, social interaction and limited repetitive behavior. One popular diet therapy for autistic patients is a gluten and casein free diet. A gluten and casein free diet based on the theory of opioids are still pro and contra to the extent that the effect of this diet needs to be investigated further. Methods: This cross-sectional observational analytic study was conducted on autistic children aged $3-12$ years who were treated in several autism therapy centers in Surabaya and were diagnosed by expert doctor. The research subjects were selected by purposive sampling method. Data on gluten and casein free diet implementation were obtained from the FFQ questionnaire and autistic behavior data obtained from the ATEC questionnaire. Results: Most autistic children are male (79\%), the average age of autistic children is 6-8 years and most of the education history of parents is college. The results obtained as many as 37 children carry out a gluten free and casein diet. Autistic symptom scores were good for communication skills, social interactions, cognitive responses and behavioral disorders in autistic children on diets rather than those who did not. Bivariate test results showed that there were significant differences in behavioral disturbance variables $(p=0.021)$ and total scores $(p=$ 0.018). While for other variables there is no difference. Conclusion: There are differences of symptom between autistic children who are gluten and casein free diet with those who are not.

Keywords: autism, diet, gluten, casein, autistic behavior 